Mr Srđan Mitrović, kapetan I klase, dipl. inž Vojna akademija,

dr Marinko Aleksić potpukovnik, dipl. inž. MTRZ „Sava Kovačević““,

mr Zoran Đorđević,

potpukovnik, dipl. inž.

Ministarstvo odbrane Crne Gore,

Podgorica

\section{MODIFIKACIJA RAČUNARSKOG DELA BRODSKOG PROTIVPODMORNIČKOG SISTEMA}

UDC: $629.5 .017 .3: 623.46]: 004.031 .43$

Rezime:

U radu je prikazana modifikacija analognog brodskog sistema za izvršenje protivpodmorničkog napada. Sobzirom na to da su analogne računarske komponente sistema zastarele, a da se većina senzora i izvršnih sklopova može zadržati, modifikacija analognog protivpodmorničkog računara je i primarni cilj rada. Prikazan je postupak analize i projektovanja novog sistema, kao i rešavanje ključnih problema sa posebnim osvrtom na rad sistema u realnom vremenu. Rezultati istraživanja $i$ testiranje funkcija sistema detaljno su analizirani. Postavljeni primarni ciljevi: povećanje efikasnosti, jednostavnije rukovanje i integracija funkcija - uspešno su ostvareni.

Ključne reči: sistem za rad u realnom vremenu, modifikacija, sistem za upravljanje vatrom, testiranje sistema, analogni sistem.

\title{
DETERMINING COMPUTER PART OF SHIP'S ANTISUBMARINE SYSTEM MODIFICATION
}

Summary:

Paper presents modification of analog ship's antisubmarine system. In regard to fact that analog computer's components are obsolete, and most of the sensors and actuators can be kept, modification of the analog computer is the primary goal of this paper. System analyses and design procedures and key problem solving are given, with special observation to real-time system functions. Research results and test of system functions are presented and analyzed in detail. Primary goals: increased efficiency, simplified handling and function integration are successfully realized.

Key words: real-time system, modification, weapon control system, system testing, analog system.

\section{Uvod}

Modernizacija postojećih zastarelih sistema kao alternativa nabavci novih sistema je svetski trend u mnogim oružanim snagama u svim vidovima. Najčešći razlog je nemogućnost ili neisplativost nabavke novog sistema. Ugrađeni brodski protivpodmornički (PPd) sistem pripada starijoj generaciji i pruža dobre osnove za modernizaciju, jer su mnoge komponente sistema još uvek funkcionalne i u dobrom stanju. Sistem se sastoji od senzora (sonar), konzole za praćenje podvodne situacije, protivpodmorničkog analognog računara i lansera dubinskih raketnih bombi. Senzor i izvršni deo sistema (lanseri) jesu komponente koje se zadržavaju, zbog svojih specifičnosti i još uvek dobrog stanja, dok su analogna računarska i upravljačka komponenta zastarele i odabrane za primarni predmet modernizacije. 
Cilj modernizacije je kraće vreme odziva sistema, tj. povećanje efikasnosti, integracija funkcija, povećana pouzdanost u radu, jednostavnije rukovanje, vremensko skraćenje obuke operatera koji je ranije posluživao analogni računar, smanjenje broja operatera, mogućnost povezivanja sa drugim sistemima novije generacije, olakšana rekonstrukcija i analiza prethodnih situacija (na starom sistemu podaci se snimaju metodom bušenja papira), olakšano i jeftinije održavanje.

Modifikacija se ne bi izvela nad celim sistemom već samo na pojedinim podsistemima, bilo njihovim modifikovanjem, bilo zamenom. U ovom radu akcenat je dat na opisu modifikacije i zamene računarskog dela sistema proverenom komercijalnom tehnologijom (engl. - commercial off-the-shelf), koja se široko primenjuje u praksi. Time se smanjuju troškovi razvoja sistema, pošto se preskače finansiranje faza ispitivanja i razvoja u životnom ciklusu sistema [1]. Softver i hardver opšte dostupne PC tehnologije je veoma napredovao u smislu kvaliteta i jednostavnosti rada, uz korišćenje različitih grafičkih interfejsa. Sistemi su otvoreni za nadogradnju, što znatno smanjuje kompletnu cenu informatičke tehnologije i zavisnost od određenog isporučioca.

\section{Analiza i projektovanje}

Stari sistem koristi analogni računar, koji rešava strogo namenske zadatke, sa ograničenom tačnošću, ali u realnom vremenu. Moguće je pratiti jedan cilj, a parametri za njegovo gađanje uvode se u lanser raketnih dubinskih bombi (RDB). Vreme pouzdanog rada sistema je ograničeno, sa značajnim opadanjem tačnosti pri produženom radu. Da bi borbeni sistem

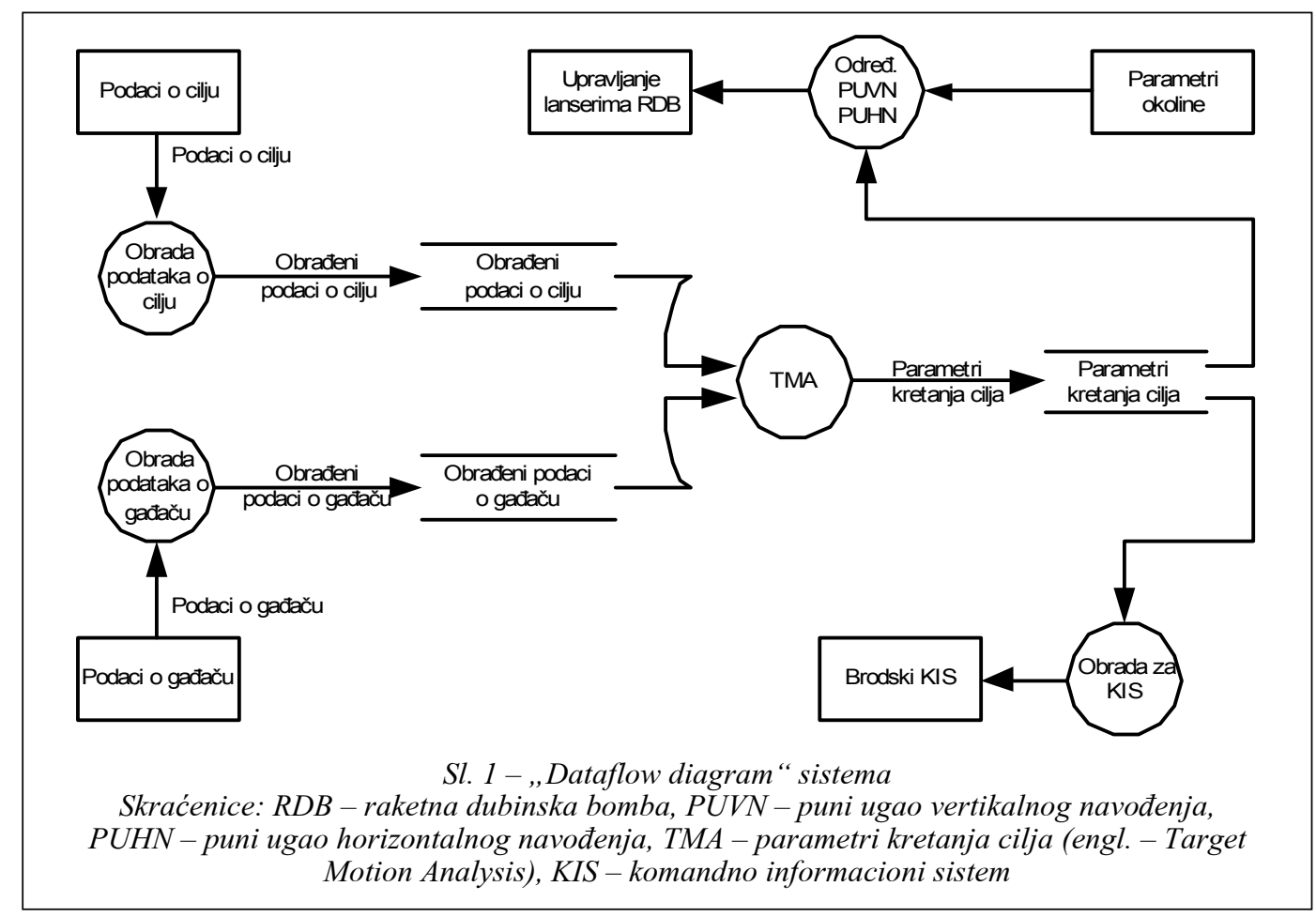


mogao funkcionisati i izvan ovog vremenskog ograničenja, ugrađena je mogućnost ručnog uvođenja parametara gađanja.

Ostale karakteristike starog sistema su: veća potrošnja energije, veliki gabariti, zastarelost sklopova i komponenti, što predstavlja problem za njihovo održavanje i nabavku rezervnih delova [1].

Zamena analognog računara računarom na bazi personalnog računara je, $u$ stvari, osnovna ideja ovog projekta, a svi ostali zadaci proizilaze iz njega.

Na sl. 1 prikazan je dijagram toka podataka najopštijeg nivoa računarskog dela sistema, bez specifikacija za korisnički grafički interfejs. Može se zaključiti da je sistem veoma kompleksan i spregnut sa različitim senzorima. Da bi modernizovani sistem zadovoljio potrebe napada na podmornicu potrebno je rešiti ključne probleme [3]. To su: sprega sa analognim sistemima; interfejs čoveka sa sistemom; sinhronizacija elemenata sistema; rad sistema u realnom vremenu.

\section{Sprega sa analognim sistemima}

Za uspešno određivanje parametara gađanja potrebno je u sistem uvesti parametre o vlastitom brodu, cilju i okolini. $\mathrm{Na}$ osnovu izračunatih parametara gađanja upravlja se lanserima raketnih dubinskih bombi. Odluka da se zadrže analogne komponente: deo elektromehanike uvođenja parametara u lansere; ugaoni davači (selsini i rezolveri), brodski senzori (sonar, brzinomer, žirokompas...) i strujni krug paljbe, nameće potrebu rešavanja problema njihove sprege sa računarskim delom sistema. U tu svrhu koristi se paleta akvizicijskih i upravljačkih integrisanih kartica koje su korišćene u modifikacijama drugih mornaričkih borbenih sistema [4]. Analogne naponske veličine sa senzora (sonar, brzinomer, žirokompas) i ugaonih davača (selsini ili rezolveri) u elektromehaničkom bloku za unošenje parametara gađanja se, uz pomoć akvizicijskih kartica, konvertuju u digitalne vrednosti, na osnovu kojih algoritam implementiran u mikrokontroleru kartice izračunava konkretnu brojnu vrednost očitane veličine. Na sl. 2 prikazana je blok-šema akvizicije podataka sa senzora čije su izlazne informacije analogne veličine.

Upravljačka kartica sadrži digitalni regulator (realizovan na mikrokontroleru kartice) i drajver za jednosmerni motor ili motor naizmenične struje.

Pomenute kartice imaju mogućnosti serijske RS-232, TCP/IP i I² C komunikacije sa ostatkom sistema. U zavisnosti od toga kome se prosleđuje informacija, bira se odgovarajući komunikacioni protokol. $\mathrm{Na}$ taj način obezbeđuju se svi neophodni ulazni podaci za modifikovani sistem.

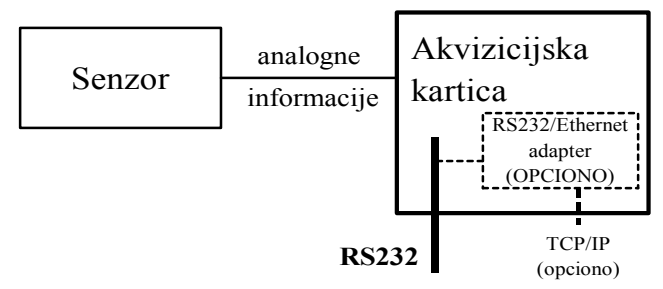

Sl. 2 - Akvizicija podatka sa senzora

Interfejs čovek - sistem

Kao osnovna radna stanica odabrana je konzola zasnovana na komercijalnim personalnim računarima, nazvana $\mathrm{PPd}$ (protivpodmornička) konzola. Za opera- 
tivni sistem je, prema zahtevu, odabran Linux sa X-Windowsom kao korisničkim grafičkim interfejsom, jer je besplatan i omogućava izvršavanje programske aplikacije sa velikog broja različitih platformi u mreži (Micro Vax, IBM RISC System 6000, Sun Sparc, Cray) [5], pa i sa MS-Windows platformi (uz instaliran XServer), a i veliki broj alata i kompajlera za program $\mathrm{C} / \mathrm{C}++$ je besplatan. Grafički interfejs realizovan je Xt stilom (predefinisane Xlib biblioteke), a korišćeni su Xaw (Athena Widget Set) widgeti. U kodu su definisani samo neophodni parametri widgeta, a ostali (dimenzije, boje, pozicija, font ...) definisani su uz pomoć alata Editres i smešteni u datoteku tipa XResource. Na ovaj način omogućene su izmene izgleda grafičkog interfejsa bez ikakve izmene koda.

Projektovanje interfejsa čovek-sistem izvršeno je nakon studiozne analize potreba korisnika. Sistem je projektovan tako da bude maksimalno jednostavan i komforan za rad. Uzeti su u obzir svi elementi postupka za izvršenje napada na podmornicu. Grafički prikaz taktičke situacije umnogome je sličan prikazu analogne konzole starog sistema, a poseduje i dodatne mogućnosti koje se jednostavno koriste. Podaci o kretanju broda i uočenom cilju kontinuirano se uvode $u$ sistem. Izračunavanje svih podataka za izvršenje gađanja se maksimalno automatizuje. Ispaljivanje raketnih dubinskih bombi iz sistema nije omogućeno, već se ta funkcija i dalje vrši preko strujnih krugova paljbe. Na sl. 3 prikazan je deo korisničkog grafičkog interfejsa. Broj operacija koje se mogu izvršavati preko ovog interfejsa je relativno mali i dozvoljava da se sve njegove funkcije nalaze $u$ jednom prozoru.

Glavni prozor sastoji se od dve celine. Jedna služi za prikaz položaja cilja u odnosu na brod, a drugi deo za nadgledanje situacije i, po potrebi, za ručno unošenje pojedinih parametara.

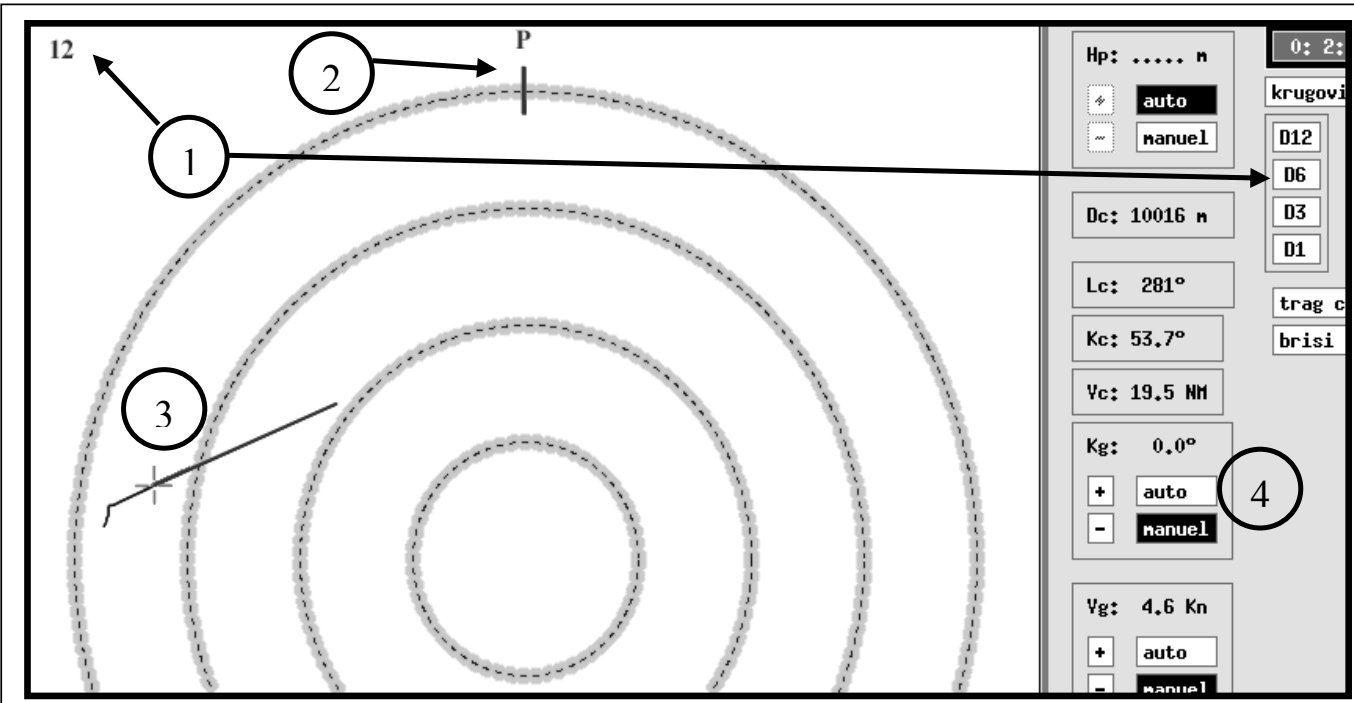

Sl. 3 - Deo korisničkog grafičkog interfejsa

1 - opseg prikazivanja, 2 - pramčanica, 3 - cilj (trag kretanja i vektor brzine), parametar Kg (kurs gađača) 


\section{Rad sistema u realnom vremenu}

Rešavanje problema računanja pozicije u svakom trenutku i izvođenje protivpodmorničkog napada spadaju u domen problema koji se rešavaju u realnom vremenu. Brodski senzor kojim se osmatraju podvodni ciljevi je aktivan uređaj sonar. On emituje akustičnu energiju u prostor, a na osnovu dela energije reflektovane od cilja dobije se odraz cilja na konzoli. Smer i daljina do cilja su podaci određeni sa tačnošću koja omogućava dovoljno precizno određivanje parametara kretanja cilja.

Parametri kretanja cilja su: brzina cilja, kurs cilja, dubina cilja i pozicija.

$\mathrm{Na}$ osnovu podataka koje nam obezbeđuju senzori sistema (daljina do cilja, smer na cilj, kurs i brzina vlastitog broda), rešavanjem ne tako komplikovanih jednačina, kao rezultat se dobija kurs i brzina cilja. Mora se uvek voditi računa o tome da sonar određuje pravu daljinu do cilja (poznatu još i kao „kosa daljina“) i da je za izračunavanje horizontalne daljine do cilja neophodan podatak o dubini cilja, koji se ne može matematički izračunati, niti odrediti pomoću sonara ugrađenog na brod. Dubina cilja se procenjuje kao taktički parametar; unapred se manuelno postavlja i može se menjati tokom izvođenja napada. Posledice velike greške u proceni dubine cilja jesu neprecizno određeni ostali parametri kretanja cilja, što dovodi do skoro sigurnog promašaja. Dakle, modernizacijom se neće izgubiti uloga komandira sistema, čije će procene i dalje biti od suštinske važnosti za uspešnost napada.

\section{Izračunavanje parametara za gađanje}

Parametri gađanja su, u stvari, i osnovni izlazni podaci računarskog dela sistema, a to su puni uglovi vertikalnog $i$ horizontalnog navođenja. Puni ugao vertikalnog navođenja (PUVN) jeste ugao između vodene linije i smera ispaljenja raketne bombe u vertikalnoj ravni, a puni ugao horizontalnog navođenja (PUHN) ugao između smera severa i smera ispaljenja raketne bombe $u$ horizontalnoj ravni.

Da bi se ovi uglovi izračunali, potrebno je odrediti tačku susreta raketne bombe i vodene površine iznad cilja. Protivpodmornički projektil je raketna dubinska bomba. Projektil do cilja putuje kroz dva različita medija - vazduh i vodu. Za proračun uglova navođenja značajna je samo putanja projektila kroz vazduh, jer kroz vodu projektil putuje pod približno pravim uglom u odnosu na površinu, pogonjen raketnim motorom, do programirane dubine ili direktnog susreta sa ciljem, gde eksplodira. Za deo putanje cilja kroz vodu za proračun je potreban samo podatak o vremenu tonjenja raketne bombe do cilja.

Za određivanje tačke susreta neophodno je poznavati parametre kretanja cilja, kretanja vlastitog broda, parametre raketne dubinske bombe, kao i atmosferske prilike (vetar, temperaturu i pritisak vazduha). Kada su poznate koordinate tačke susreta moguće je odrediti i uglove navođenja lansera, ali samo u onom koordinatnom sistemu u kojem je rešavan problem susreta - u koordinatnom sistemu stabilizovanog broda. Lanseri se moraju navoditi po uglovima koji se određuju u odnosu na palubu broda koji se valja. Zbog toga se stabilizovani uglovi navođenja preračunavaju u pune uglove na- 
vođenja sa uračunatim valjanjem broda. Tako dobijene vrednosti PUHN-a i PUVN-a prenose se u sistem upravljanja lanserima, koji ih zakreće u horizontalnoj i vertikalnoj ravni prema elementima iz računara.

Uglovi horizontalnog i vertikalnog navođenja lansera mogu se odrediti na dva načina: očitavanjem iz lookup tabele gađanja ili proračunom odgovarajućim formulama. Zbog tajnosti, tabele ili formule se ugrađuju u sistem tek pošto se odobri njegova ugradnja na objekat, pa su u radu analizirani samo parametri neophodni za izračunavanje parametara gađanja.

Sa stanovišta rada sistema u realnom vremenu, matematički problem koji se rešava zahteva ograničen broj jednostavnih jednačina čije je vreme rešavanja konstantno, jer ne sadrže petlje. Za dobijanje korektnog rešenja najvažnije je obezbediti vremensku relevantnost svih ulaznih podataka, što znači da svi ulazni podaci za jednačine moraju da se odnose na isto početno vreme [6]. Ulazne veličine se generalno mogu podeliti na tri grupe (sl. 1): parametre cilja, parametre broda i parametre okoline.

Parametri okoline su u odnosu na ostale dve grupe sporo promenljivi, te ih nije potrebno korigovati za vreme proteklo od njihovog poslednjeg unosa do trenutka u kojem se vrši proračun. Sa sadašnjim brodskim senzorima ovi parametri mogu se uneti jedino ručno, pa je interval njihovog ažuriranja veliki.

Parametri cilja i parametri vlastitog broda sastoje se od grupe veličina (vektor brzine i položaj u prostoru), čija se vremenska relevantnost u okviru grupe postiže dvostrukim baferovanjem [6], s obzirom na to da dolaze $u$,istom" trenutku, ali sa različitih interfejsa. Za proračun tačke susreta potrebno je i parametre vlastitog broda i para- metre cilja preračunati na vrednosti koje se odnose na trenutak ispaljenja raketne bombe, što znači da se u proračun uvodi vreme proteklo od poslednjeg ažuriranja do trenut$\mathrm{ka}$ ispaljenja. Zbog spore dinamike kretanja broda gađača i cilja, vreme od trenutka proračuna do ispaljenja može se i zanemariti, što znači da je trenutak završetka proračuna istovremeno i trenutak ispaljenja. Da ovo zanemarivanje ne bi dovelo do greške, očigledno je da se lanseri u trenutku proračuna već moraju nalaziti u zadatom položaju. Parametri navođenja lansera iz računarskog dela kontinuirano se dovode do uređaja za upravljanje lanserima, kao što se i proračun tačke susreta vrši neprekidno. Očigledno je da se lansiranje raketnih bombi može izvršiti tek pošto se i vertikalni i horizontalni ugao lansera poklopi sa zadatim uglovima. Vreme potrebno za dovođenje lansera u položaj za ispaljivanje od trenutka uključenja uređaja za upravljanje lanserima zavisi od položaja cilja u odnosu na brod, i reda je nekoliko sekundi, nakon čega lanseri neprekidno „prate“ cilj na osnovu podataka prispelih iz PPD računara.

\section{Upravljanje lanserima dubinskih bombi}

Odlika ovog sistema jeste da se akvizicija podataka sa senzora i zakoni automatskog upravljanja servo sistemima lansera realizuju lokalno na nivou mikrokontrolera. Na sl. 4 prikazana je blok-šema uvođenja jednog parametra gađanja. Elektromehanički blok sastoji se od jednosmernog motora ili motora naizmenične struje, analognog davača ugla (selsin ili rezolver), što određuje tip akvizicijske i upravljačke kartice. Komunikacija između kartica odvija se po $\mathrm{I}^{2} \mathrm{C}$ protokolu. Računari konzola sa upravljačkim i akvizicijskim karticama komuniciraju 


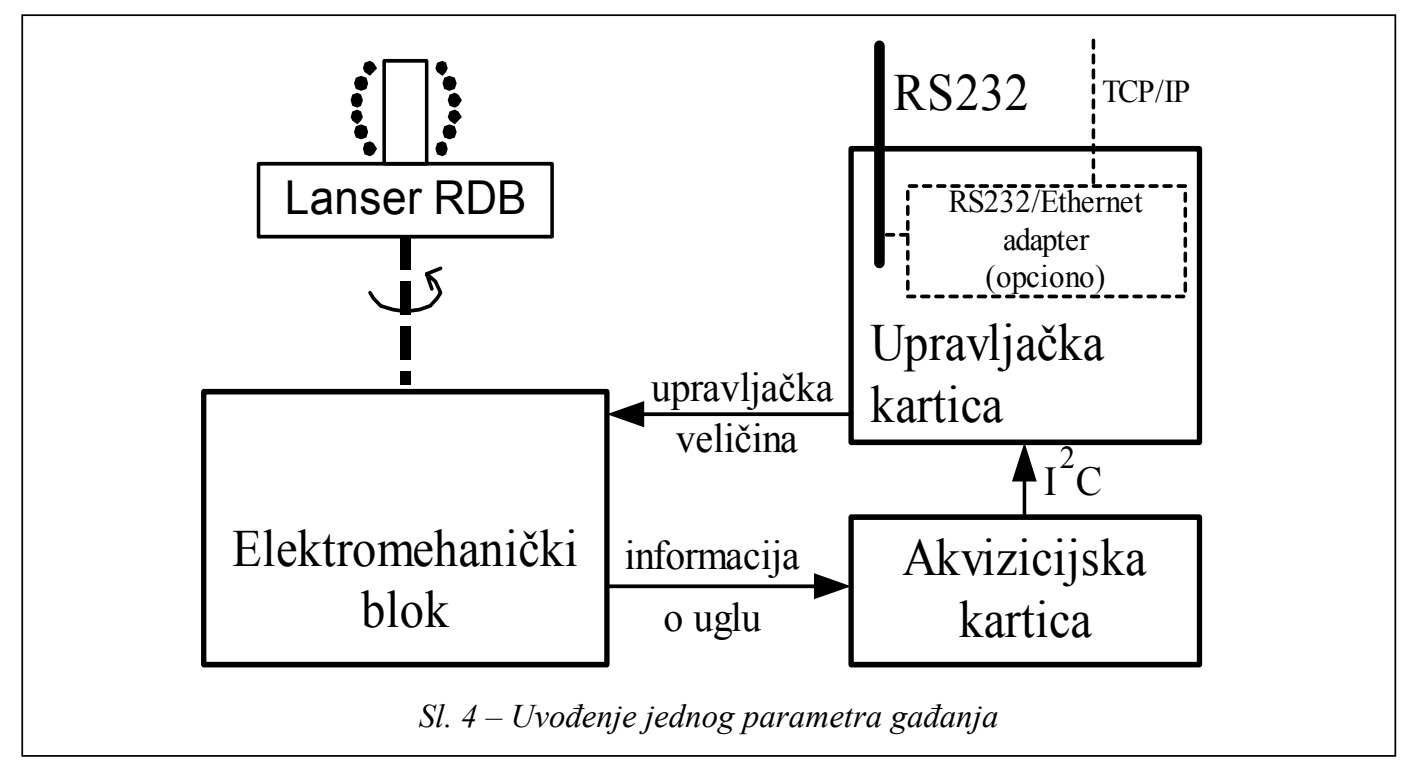

po RS-233 protokolu (sa mogućnošću nadogradnje na TCP/IP). Lokalna realizacija zakona upravljanja i akvizicije podataka rasterećuje saobraćaj ka PPd računaru i povećava robustnost sistema. Zadavanje naređenih veličina, proveru njihovog odrađivanja i obnavljanje podataka sa senzora, PPd računar vrši puno dužom i ne tako fiksnom periodom.

\section{Implementacija i verifikacija}

Matematička složenost zadatka koji sistem rešava nije velika, ali broj ulaznih veličina i njihova priroda, interfejsi prema različitim analognim sklopovima i veliki značaj zadatka koji se rešava, čine ga kompleksnim. Zbog toga je softver implementiran i testiran postepeno i modularno, sa završnim testiranjem svih funkcija sistema.

\section{Hardver za testiranje}

Prvi složeniji zadatak koji je rešavan jeste komunikacija sa akvizicijskom karticom i prikaz očitane veličine. Testi- ranje ove funkcije vršeno je prema sl. 5, ali se akvizicija nije obavljala sa senzora, već sa selsina koji se zakreće ručno. Tačnost očitavanja isključivo zavisi od akvizicijske kartice (greška je u granicama tolerancije), što znači da se za PPd softver proveravala samo komunikacija i korektnost prikazivanja podatka.

Sledeća implementirana i testirana funkcija bila je prikazivanje cilja i pripadajućih mu podataka na grafičkom interfejsu. Pošto su za prikazivanje cilja istovremeno potrebna dva podatka (daljina $\mathrm{i}$ ugao na cilj), bilo je neophodno modifikovati hardver kao na sl. 5. Korišćena su dva rezolvera (SKVT) i dve akvizicijske kartice, jedan par za daljinu do cilja, a drugi za ugao na cilj. Na taj način uspešno je testirano prikazivanje oznake cilja, vektora brzine i traga kretanja za nepokretan i pokretan cilj i/ili brod gađač i različite opsege prikazivanja (krugovi daljine).

Pomoću opisanog hardvera uspešno je testiran unos i prikaz ostalih ulaznih veličina u sistem. 


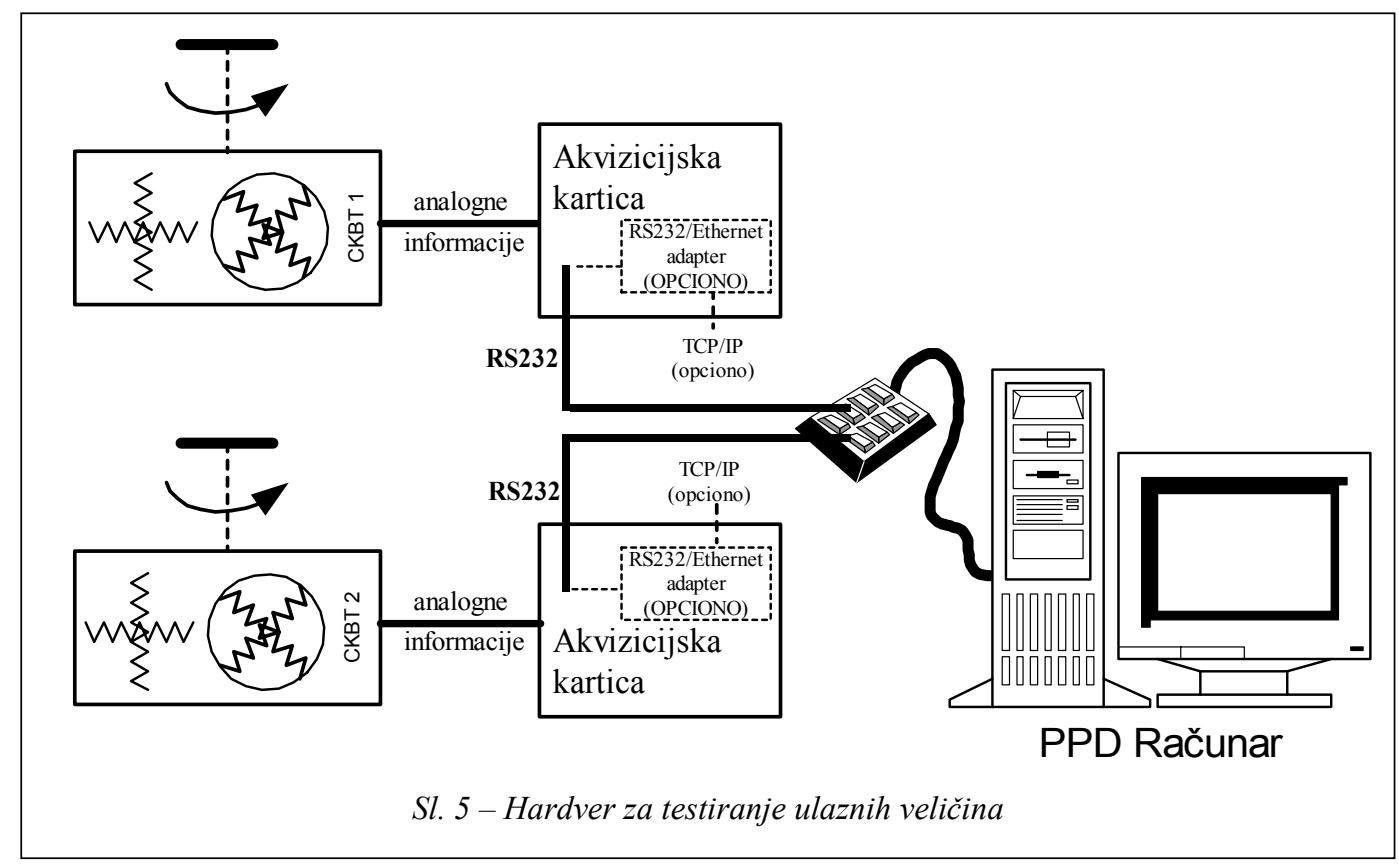

Pored znatnih prednosti testiranja PPd softvera uz pomoć ovog hardvera, ističe se jedan veliki nedostatak. Iako je rečeno da je softver testiran $\mathrm{i}$ za cilj $\mathrm{i}$ brod gađač u pokretu, korektnije bi bilo reći da se odnosi samo na brod gađač. Naime, stvarni cilj vozi brzinom i u kursu koji su nepoznati i sporo promenljivi, rezolverima koji se ručno okreću simulira se daljina i ugao na njega, te je operateru na test-hardveru nemoguće da ručno sinhronizuje rezolvere i korektno simulira cilj koji se kreće. Čak i vrlo lagano okretanje rezolvera, kao rezultat daje nagle promene kursa i brzine cilja u PPD softveru. Kretanje vlastitog broda i prikaz numeričkih i grafičkih podataka (linija pramca) uspešno su testirani ovim hardverom za brod sa nultom brzinom, a pošto je moguće iz PPd softvera ručno unositi podatke o vlastitom brodu, brod $\mathrm{u}$ pokretu simuliran je samim PPd softverom.
Određivanje parametara kretanja cilja i parametara za gađanje (PUVN i PUHN) uspešno je testirano samo za cilj sa nultom brzinom i za brod gađač u pokretu. Rezultate dobijene za cilj koji se kreće nije moguće verifikovati zbog nepoznatih i jako oscilujućih parametara kretanja, čiji je uzrok ranije opisan.

\section{Softver za testiranje}

Pošto test-hardver ne omogućava kompletno testiranje funkcija PPd softvera, kao rešenje nameće se projektovanje softverskog test-modula. Korisnički grafički interfejs ovog modula prikazan je na sl. 6.

On-Off dugme služi za uspostavljanje, prekid i nastavak komunikacije sa PPd softverom. U sledećem bloku prikazuje se vreme proteklo od inicijalizacije komunikacije. K0 i D0 određuju početnu poziciju cilja u odnosu na brod (ugao i daljina). U 


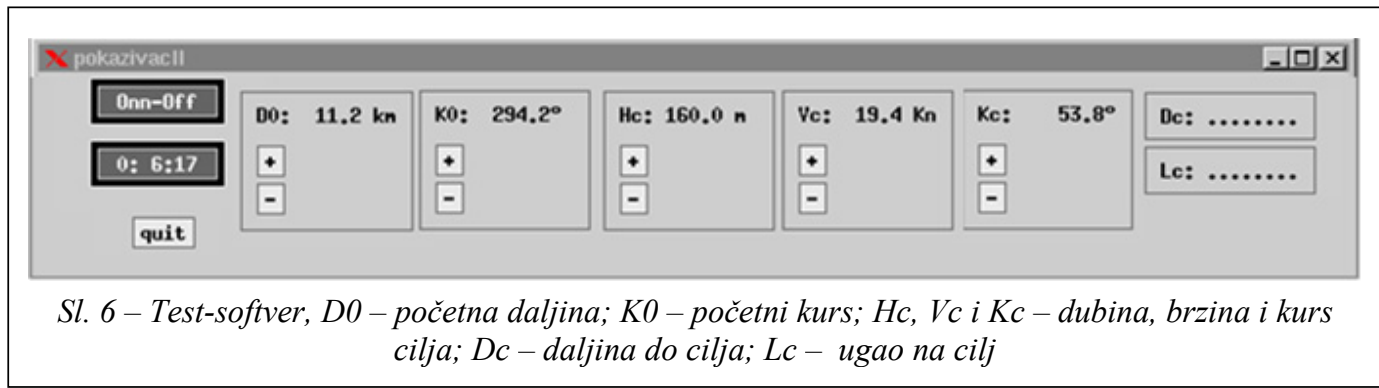

Hc bloku postavlja se dubina podmornice (cilja), Vc je brzina cilja, a Kc njegov kurs. Daljina do cilja je Dc, a Lc ugao na cilj i to su podaci koji se šalju PPd softveru. PPd i test-softver komuniciraju preko virtuelnog porta (socket), koji se nakon inicijalizacije i uspostavljene komunikacije koristi kao i bilo koji drugi port (npr. RS-232).

Komunikacija je dvosmerna (sl. 7). PPd softver prema test-aplikaciji šalje podatke o vlastitom brodu $(\mathrm{Kg}, \mathrm{Vg}) . \mathrm{Na}$ osnovu ovih podataka i zadatih parametara kretanja cilja (Hc, Kc, Vc, D0, K0) test-softver izračunava daljinu i ugao na cilj (Dc, Lc) i šalje ih PPd softveru. $\mathrm{Na}$ ovaj način simuliraju se podaci o realnom cilju koje bi PPd softver primao sa sonara. Test-aplikacija nam sada omogu-

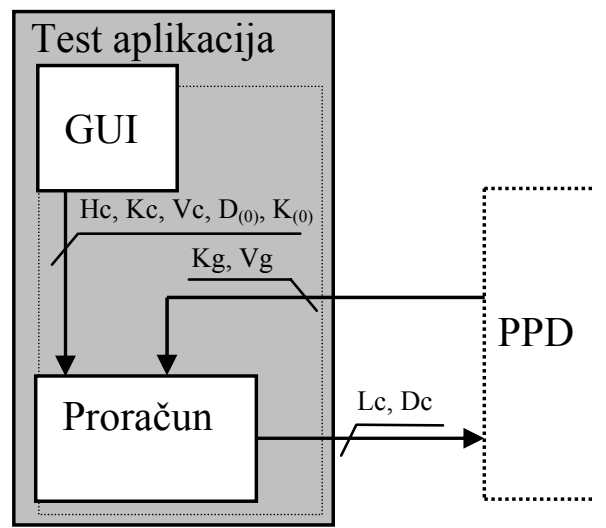

Sl. 7 - Ulazi i izlazi test-aplikacije, GUI-grafički korisnički interfej; Hc, Kc $i$ Vc-dubina, kurs $i$ brzina cilja; $D_{(0)}$ - početna daljina; $K_{(0)}-$ početni kurs; $K g, V g-k u r s i$ brzina gađača;

Dc - daljina do cilja; Lc - ugao na cilj ćava potpuno testiranje PPd softvera, kako funkcionalnosti njegovog grafičkog interfejsa, tako i korektnosti proračuna. Uz startovanje ovih aplikacija sa displeja različitih računara i uvođenje ograničenja brzine cilja i gađača moguće je izvesti i manje „ratne igre“, što znači da bi se test-aplikacija uz ili bez izmena mogla koristiti za trenažu operatera.

Jedan od dopunskih zahteva jeste snimanje u datoteku svih relevantnih podataka o kretanju broda gađača i cilja. Rešenje ovog zahteva moguće je iskoristiti radi testiranja PPd softvera. $\mathrm{Za}$ to je potrebno da se, osim podataka o cilju i gađaču koje PPd softver upisuje u datoteku, omogući i test-aplikaciji da upisuje zadate podatke o cilju. Pošto PPd softver ovu datoteku kreira iznova za svako pokretanje softvera sa drugim nazivom (IME_VremeStarta.dat), upisuje se u kurir datoteku za upoznavanje test-aplikacije sa validnim nazivom. Analizom ovih podataka moguće je utvrditi da li je greška određivanja parametara kretanja cilja u dozvoljenim granicama.

\section{Analiza procene parametara kretanja cilja}

Za analizu greške korišćeni su podaci iz test-aplikacije u različitim režimima plovljenja cilja i broda gađača. Maksimalne dozvoljene greške su 1 čvor (za brzinu) 
i $1^{\circ}$ (za kurs). Analizom snimljenih podataka moguće je ustanoviti vrednost greške u simuliranim režimima plovljenja. Za analizu su odabrani karakteristični očekivani uslovi rada sistema u realnom okruženju, pokriveni su svi kursevi i brzine cilja i gađača, u ograničenom broju kombinacija. Pošto su za proračun značajni podaci o relativnim parametrima kretanja i položaju cilja (u odnosu na brod), a radi jednostavnijeg opisa scenarija, u daljim analizama razmatrano je samo relativno kretanje cilja. Takođe, pretpostavljeno je da se cilj kreće na konstantnoj dubini, koja je ispravno procenjena. Dobijeni rezultati prikazani su na sl. 8 .

Prvi red na slici prikazuje rezultate kada se cilj kreće konstantnom brzinom i ne menja kurs. To je i najčešća situacija pri gađanju ukoliko gađač prvi uoči cilj.

Drugi red predstavlja scenario kada je kurs cilja konstantan, a brzina se menja po zakonu: $\mathrm{Vc}_{(\mathrm{kT})}=\mathrm{Vc}_{(\mathrm{kT}-\mathrm{T})}+0,2 \mathrm{KN}$, gde je kT trenutak poslednje potvrde cilja, a (kT-T) trenutak pretposlednje potvrde, gde $\mathrm{T}$ predstavlja interval između

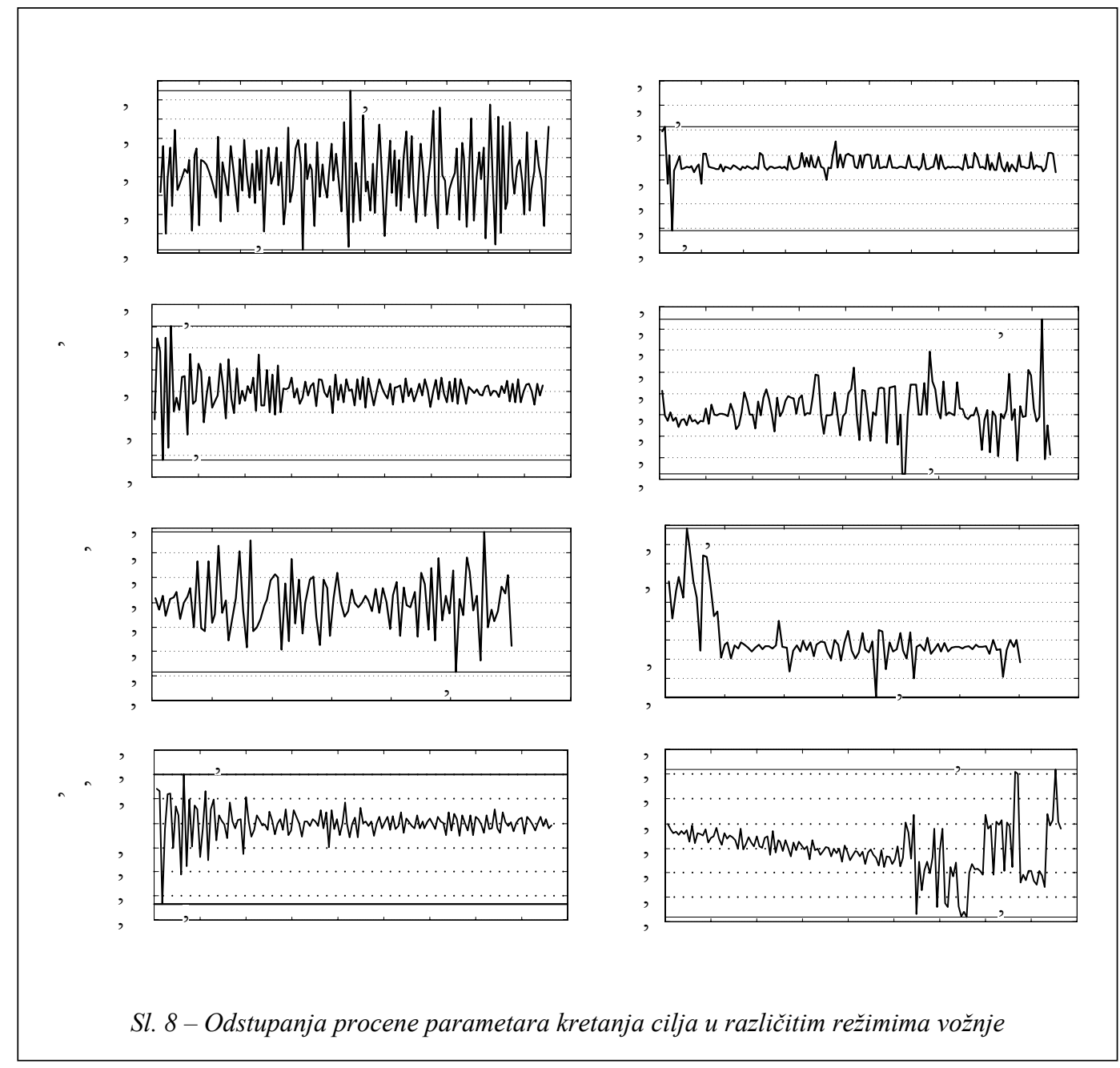


dve potvrde na cilj. Ovaj scenario približno odgovara izvlačenju (bežanju) cilja iz opasne zone.

Treći red na sl. 8 prikazuje odstupanje procene parametara, kada cilj vozi konstantnom brzinom, a kurs se menja po zakonu $\mathrm{Kc}_{(\mathrm{kT})}=\mathrm{Kc}_{(\mathrm{kT}-\mathrm{T})}+3,2^{\circ}$. To je scenario izbegavanja i dovođenje cilja $u$ bezbednu zonu za eventualni protivnapad (sa suprotne strane broda gađača).

Poslednji scenario na sl. 8 ne odgovara realnim taktičkim situacijama, ali prouzrokuje permanentne i velike promene parametara kretanja cilja, te je samo zbog toga i razmatran.

\section{Analiza procene parametara kretanja cilja}

Rezultati testiranja

\begin{tabular}{|c|c|c|c|c|c|c|}
\hline \multirow{2}{*}{ Sc. } & \multicolumn{3}{|c|}{$\Delta \mathrm{Kc}\left[{ }^{\circ}\right]$} & \multicolumn{3}{c|}{$\Delta \mathrm{Vc}[\mathrm{KN}]$} \\
\cline { 2 - 7 } & maks. & min. & maks. $\mid \Delta \mathrm{Kc}$ & maks. & min. & maks. $|\Delta \mathrm{Vc}|$ \\
\hline 1. & 0,225 & $-0,192$ & $\mathbf{0 , 2 2 5}$ & 0,226 & $-0,620$ & $\mathbf{0 , 6 2 0}$ \\
\hline 2. & 0,605 & $-0,644$ & $\mathbf{0 , 6 4 4}$ & 0,443 & $-0,275$ & $\mathbf{0 , 4 4 3}$ \\
\hline 3. & 0,286 & $-0,287$ & $\mathbf{0 , 2 8 7}$ & 0,243 & $-0,197$ & $\mathbf{0 , 2 4 3}$ \\
\hline 4. & 0,400 & $-0,670$ & $\mathbf{0 , 6 7 0}$ & 0,221 & $-0,381$ & $\mathbf{0 , 3 8 1}$ \\
\hline \multicolumn{3}{|c|}{ maks. } & $\mathbf{0 , 6 7 0}$ & maks. & $\mathbf{0 , 6 2 0}$ \\
\hline
\end{tabular}

U tabeli su prikazana maksimalna odstupanja procene parametara kretanja cilja dobijenih pomoću test-aplikacije za četiri prethodna scenarija. Najvažniji zaključak koji sledi jeste da maksimalna greška procene parametara kretanja cilja nikad ne prelazi dozvoljenu grešku. Opisanim načinom testiranja PPd softvera može se samo konstatovati da su rezultati proračuna u okviru zadatih specifikacija [6], ali se ne može tvrditi da oni nikad neće premašiti te granice. Zbog toga, iako je ovo testiranje u dosadašnjem veku PPd softvera bilo najkompleksnije, nikako ne treba zapostaviti i testiranja izvršena pomoću test-hardvera. Uzimajući u obzir celokupne rezultate provere od pojedinačnih modula do integralnog softvera, budući da se ni jednom nije manifestovao otkaz ili nedozvoljena greška procene, može se konstatovati da PPd softver ispunjava neophodne kriterijume.

S obzirom na način testiranja pomoću test-aplikacije, moglo se pretpostaviti da će greške procene biti mnogostruko manje (iako se to ne zahteva). Korišćeni operativni sistem Linux nije specijalizovan za rad u realnom vremenu, a pošto je ovo sistem namenjen za rad $\mathrm{u}$ realnom vremenu i rezultati proračuna direktno zavise od merenja vremena, sve greške vezane za tačnost merenja intervala između dve naznake na cilj direktno se manifestuju u grešku procene parametara kretanja cilja. Vremenski interval u svim scenarijima testiranja se kretao između 2 i $3 \mathrm{~s}$, a to pri maksimalnim brzinama cilja odgovara pomeraju od $15 \mathrm{~m}$ između dva intervala potvrde kontakta, što je 3 do 7 puta manje od dimenzija samog cilja. Ako se uzme u obzir da se potvrda kontakta daje ručno, greška merenja vremena je čak i poželjna u svrhu testiranja. U realnim situacijama najmanji interval potvrde kontakta je reda $5 \mathrm{~s}$, iz čega se zaključuje da greška procene ne bi bila veća od grešaka iz tabele. Na osnovu toga moguće je zaključiti da nema potrebe za reimplementacijom softvera pod neki drugi operativni sistem namenjen za rad u realnom vremenu, jer i ova implementacija u potpunosti zadovoljava postavljene zahteve. 


\section{Zaključak}

Životni ciklus opisanog PPd sistema nije završen. Zbog poteškoća, koje nisu predmet ovog rada, on nije stigao do faze integracije u realno okruženje. Svi postavljeni zahtevi za akviziciju ulaznih podataka, u pogledu funkcionalnosti korisničkog grafičkog interfejsa, kao i dopunski zahtevi, uspešno su realizovani i implementirani.

Sa stanovišta izlaznih podataka (uglovi navođenja), kao što je i ranije navedeno, obezbeđeni su svi podaci neophodni za njihov proračun, pa se s pravom pretpostavlja da bi njihova implementacija bila uspešno realizovana po dobijanju odgovarajućih jednačina ili tabela gađanja.

Može se konstatovati da se uz trenutno raspoloživu tehniku i tehnologiju stari analogni protivpodmornički računar može uspešno zameniti računarom na bazi personalnog računara, uz već usvojene hardverske modifikacije.
Sistem je otvoren za dalje usavršavanje. Za neku sledeću nadogradnju ili modifikaciju korisno bi bilo vizualizovati stanje i položaj lansera RDB. Takođe, predlaže se da se određivanje parametara kretanja cilja, sem linearno, obradi i složenijim metodama procene parametara kretanja objekta. Sa stanovišta taktike za donošenje odluke bilo bi od pomoći ugraditi proračun verovatnoće pogotka cilja, u zavisnosti od trenutne situacije na vojištu i broja ispaljenih RDB.

Literatura:

[1] „COSSI - Commercial Operational and Support Savings Initiative", Office of the Under Secretary of Defense for Acquisition, Technology and Logistic, Washington DC, USA, 2001.

[2] Đorđević, Z., Aleksić, M., Mitrović, S.: „Koncepti modernizacije brodskih upravljačkih sistema“, 20. godišnjak Fakulteta za pomorstvo, Kotor, 2003.

[3] Mitrović, S., Đorđević, Z., Aleksić, M.: „Modernization of Submarine Torpedo System“, ETF Journal of Electrical Engineering, EE Department, University of Montenegro, May 2004.

[4] „Orca 2000 - Navigational and Torpedo system, Technical Manual“, MTRZ „Sava Kovačević“, Tivat, 2000.

[5] Keller, B. J.: „A Practical Guide to X Window Programming“", CRC Press, USA, 1998

[6] Laplante, P. A.: „Real Time System Design and Analysis, an Engineer's Handbook“, IEEE Press, New York, 1997. 